\title{
Correlation Between Visual Improvement and Behavior Change of Municipal Solid Waste Management in Jodipan and Ksatrian Village, Indonesia
}

\author{
Prasanti Widyasih Sarli ${ }^{1}$, Nida Maisa Zakiyya ${ }^{2}$, Prayatni Soewondo ${ }^{2}$ \\ Programmed Study of Civil Engineering, Faculty of Civil and Environmental Engineering, Bandung Institute of \\ Technology, Indonesia ${ }^{l}$ \\ Programmed Study of Environmental Engineering, Faculty of Civil and Environmental Engineering, Bandung \\ Institute of Technology, Indonesia ${ }^{2}$
}

\begin{abstract}
Indonesia, as a developing country, has many slum areas. Over the years, there have been many projects specifically targeting the improvement of slum areas, both at a national or regional level. One example of such project can be observed in Malang City, East Java, where visual improvements of a slum area is attempted by the application of colorfull paints throughout the settlements. Two of the initial projects are Jodipan and Ksatrian Village that are located on the riverside area of Brantas River, one of the biggest river in East Java. The original idea firstly came to Jodipan Village to improve the cleanliness of the area. As the Jodipan Village improved, this village became a local tourism area. Due to its success, the painting project was then adopted to the Ksatrian Village across the river. Before the project, the residents of the villages were used to throw their municipal solid waste to the river. Since the improvement projects ran, it has been found that the improvement can be linked to residents' awareness for municipal solid waste management. This study focuses on the correlation of visual improvement and behavior change of municipal solid waste; and the differences between the correlations in each village (Jodipan and Ksatrian). A descriptive model was done by observation and questionnaire to the 48 residents of Jodipan Village and 69 residents of Ksatrian Village, with a tolerance for error of 0,1 and confidence level of $90 \%$.
\end{abstract}

Keywords-behavior change, municipal solid waste, slum area.

\section{INTRODUCTION}

G reater access to sanitation in the form of municipal solid waste in developing countries is urgent. This is especially true at the urban setting, where increase in population density amplifies the already existing problems of sanitation.

Of the 1.9 billion people who gained access to improved sanitation between 1990-2011, 1.1 billion live in urban areas. However, even though urban areas are better served than rural areas, urban areas are still struggling to keep up with the urban population growth [1]. Rapid urbanization in developing countries creates massive demand for basic infrastructure in cities. As a result infrastructure development lags behind the population growth especially in low-income areas [2].

In Indonesia, about $53.7 \%$ of the population lives in urban areas [3], and of the $59 \%$ of the Indonesian population that has adequate access to sanitation facilities [4], 59.2\% live in urban settings [5]. Solid waste-collecting systems are uncommon; in 2008 the waste management authority served only $56 \%$ of the population [6,7]. Out of the $59,100,000$ ton of municipal solid waste generated pear year in Indonesia, it is estimated about $25 \%$ ends up in unsound disposal [8].

The Indonesian government is however dedicated to improve the situation by putting a target of $100 \%$ access to sanitation and complete eradication of slums by the year 2019 [6]. Although more support is given to the improvement of sanitation due to these targets, it is estimated that less than $2 \%$ of the national and regional budget goes into sanitation. Therefore sanitation facilities cannot operate in its full capacity because of the lack of operational and maintenance budget [4]. Due to this limited state budget, many small, privately funded and alternative area improvement projects, which involve community participation, have sprung in Indonesia.

A research in India found that the cost per ton of waste management with community participation is only $79 \%$ of the cost per ton of waste by the government run Municipal Corporation of Greater Mumbai, while public private partnership is at $94 \%$ [9]. However, the sustainability of this type of public-community participation cannot be ensured, even when introduced in areas with smaller size of operation, because of the voluntary nature of the service provided by the communities, low involvement of private agencies and inappropriate choice of methods for recycling [10].

In Indonesia, a study performed in Semarang, Central Java, has shown that a community-based waste management system can change people's behavior by reducing waste up to $33 \%$ [11]. However in Jakarta a study has shown that the success of municipal solid waste management is better when handled by neighborhood-based organizations rather than community based organisations, the difference being that neighborhood based associations are more formal, locally elected and typically acknowledged within the local government structure and therefor garner more respect from the residents [12]. 
Although there is much urgency to understand the factors that affect different stages of waste management and the possible individual behavior change necessary to generate a working waste handling system in developing countries, there are still too few articles that give quantitative information on this issue. Information on best practices in acceleration of municipal solid waste management becomes crucial in order to plan, change and implement new municipal management systems in cities.

The Jodipan and Kesatrian Project is one alternative project that tries to deal with behavior related to municipal solid waste handling, especially to littering. The project was proposed by students from the University of Muhammadiyah Malang (UMM) in collaboration with PT Indana, a paint company, as a form of Corporate Social Responsibility platform to improve the visual appearance of the slum and therefore motivate the residents to adopt a cleaner lifestyle. The residents were used to throw municipal solid waste directly into the river prior to the project, and it is this behavior that the project aims to change. Although the projects initial goal was only for the residents benefit, it quickly became a tourist destination.

In this research, the question of whether the visual improvement of the slums did indeed succeed in changing the behavior of the residents towards waste management is being investigated. The components that resulted in the success of this project are also identified.

\section{METHODOLOGY}

In order to identify the components that resulted in the success of Jodipan and Kesatrian, in this research a descriptive model is used to investigate in depth the nature and timeline of the project. The descriptive model is build by using data from

1. Expert interview with stakeholders related to the project, which include

a. Representative of the company who is the funder of the CSR Project that resulted in the Jodipan and Kesatrian program, PT Indana

b. Students who are the initiators of the project, Guys Pro

c. Academic Lecturer from UMM who was the supervisor of the students during the project

d. Head of the Community

2. Preliminary survey done by the students of UMM to gather qualitative data of the residents before the visual improvement project

3. Quantitative survey of both the residents of Jodipan and Kesatrian was performed. From this data the sanitation status as well as residents preference for improved sanitation and the initial economic set up with the economic impact the project has given is investigated.

Further details on the methodology used in this research is given in the subsequent sections

\section{A. Data Collection}

Questionnaire was used to collect qualitative data and they were administered between February to April 2017. The questionnaires were formulated to collect data from households residing in the area of study. The sampling of residents was random and questionnaires were administered to a total of 117 households; 48 households from Jodipan and 69 households from Ksatrian. This sample size was considered representative, with a margin of error calculated by using the Slovin Method of only $1 \%$. The questionnaire captured

1. Demographic aspects

2. Socio-cultural and socio-economic aspects

3. Attitude towards solid-waste management

4. Sanitation facility preferences

5. Water supply sources

6. Sanitation facilities currently in use

For the municipal solid waste category, the questionnaire captured the change of behavior of the residents before and after the project measured the awareness of residents towards waste management systems. The questionnaire also took into account the volume of trash thrown by each household by classifying it into small, medium and large trash bags; which each corresponds to a capacity of $0.7 \mathrm{~L}, 4 \mathrm{~L}$ and $30 \mathrm{~L}$ of trash.

\section{B. Data Analysis}

The data collected through the questionnaires from residents was analyzed using SPSS and MS Microsoft Excel. Simple statistics where used to investigate the demographics and the physical reduction of waste.

In order to evaluate the impact of the project to the awareness of the residents towards municipal solid waste management, a Paired Sample T-test is conducted. In order to calculate the effect size, the $\eta^{2}$ is calculated as follows

Where,

$$
\eta^{2}=\frac{t^{2}}{t^{2}+(n-1)}
$$

$$
\begin{aligned}
t & =\frac{\bar{x}_{\text {diff }}}{s_{\bar{x}}} \\
s_{\bar{x}} & =\frac{s_{\text {diff }}}{\sqrt{n}}
\end{aligned}
$$

Where $\bar{x}_{\text {diff }}$ is the sample mean of the differences, $n$ is the sample size, $s_{\text {diff }}$ is the sample standard deviation of the differences and $s_{\bar{x}}$ is the estimated standard error of the mean, typically calculated as $s / \sqrt{n}$.

\section{DESCRIPTION OF THE PROJECT}

The description of the project is obtained mainly by using the qualitative data from the expert interview mentioned in the methodology; the detail description of the area and project is presented below. 


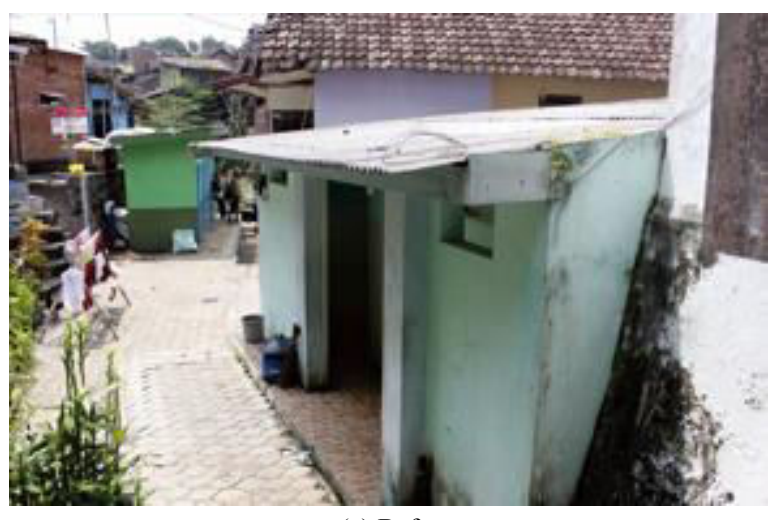

(a) Before

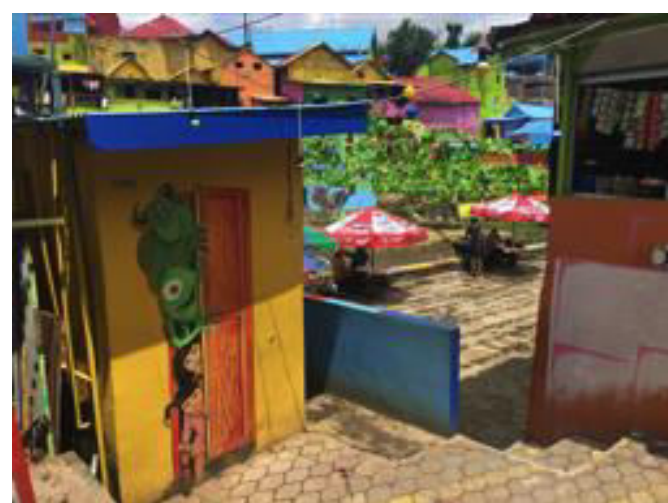

(a) After

Figure 1 Area inside of Jodipan before and after the visual improvement

\section{A. Area Description}

Jodipan and Kesatrian are two administrative subdisctrict (Kelurahan) in the district of Bllimbing, Malang. A small part of both of these Kelurahan are located around the riverside of Brantas River, according to the Government Order PP 2011 on Rivers these areas are considered illegal neighborhoods, the residents however have been occupying the area for more than 10 years. Jodipan has 91 households while Ksatrian has 220 households. Both areas have public facilities that include a mosque, public toilets and public bathrooms. See figure 1.a for a visual on the area inside Jodipan before the visual improvement project.

Preliminary research by UMM students done before the project found that $90 \%$ of the residents of Jodipan threw away their trash directly into the river, the reason being that 1) the distance to the nearest temporary garbage disposal is significantly far, while the river is nearby, 2) resident do not think that their action affects the rivers outpour, stating that the flooding of the river is due to the activities upstream of the river.

The initial municipal solid waste management system is non-existent in Jodipan, therefore residents were expected to throw their municipal solid waste to the Temporary Waste Collection Location (Tempat Penimbunan Sampah Sementara-TPS), located far away from their respective houses. In Ksatrian however there already is a collecting system from each household that delivers the municipal solid waste to the Temporary Waste Collection Location. For this system, the fee for each household in Ksatrian is at 0.75 USD per month.

\section{B. Project Description}

In February 2016, a group of students from the Communication Department of Muhammadiyah Malang University initiated a project to paint parts of the Jodipan area with bright colors. The students collaborated with Indiana Paint, a local company in Malang, to receive help in the form of the paint and funding. PT. Indana welcomed the students Initiative and used the project as a Corporate Social Responsibility platform for their brand Decofresh. The project, tittle "Decofresh Mewarnai Jodipan" or "Decofresh Colouring Jodipan", was initiated as part of a Public Relations Class. Its affiliation with an ongoing class, gave a one-semester time frame for the completion of the project, starting from February to June 2017.

The Projects main purpose is to fulfill the duty of the Public Relations CSR of the company. The project needed to fulfill the triple bottom line of CSR, which stressed the companies' action to focus on the sustainable impact of the project economically, socially and environmentally. Both the students and the company designed the project not to only help the residents, but also as a tool for better public recognition for the company. Therefore the choice of the location became crucial.

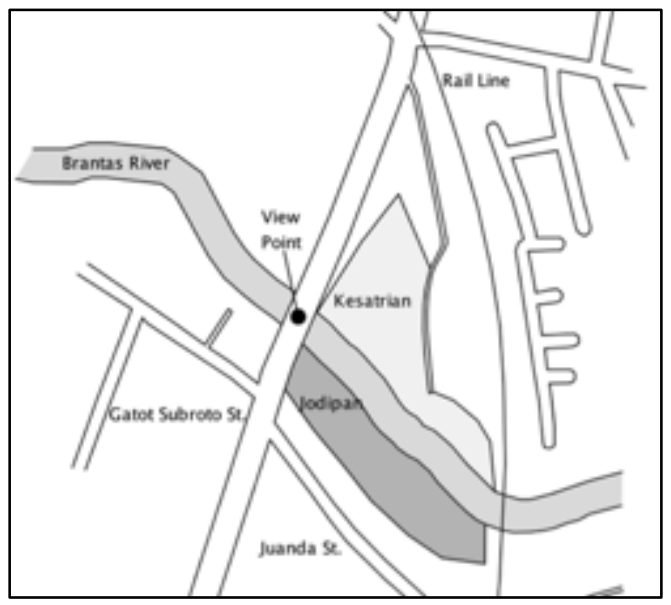

Figure 2 Map of the Project

In Malang, there are 26 areas that are considered to be slums, but most of them are not visible from the main street, resulting in a smaller impact for the company if those areas were to be chosen for the project. Jodipan therefore became a convenient choice due to its visibility from one of the main streets in Malang and its scenic position. The area was particularly chosen for its visibility from the Gatot Subroto Bridge, so that it can become a good viewpoint for bypasses. Additional consideration in favor for Jodipan was the clear view of the rail-line bridge from the viewpoint, which increased the visual appeal of the area (see figure 2 for clarity).

The students collaborated with the local residents, military officers, and also workers from the company to paint the neighborhood. Local Mural Artist communities 


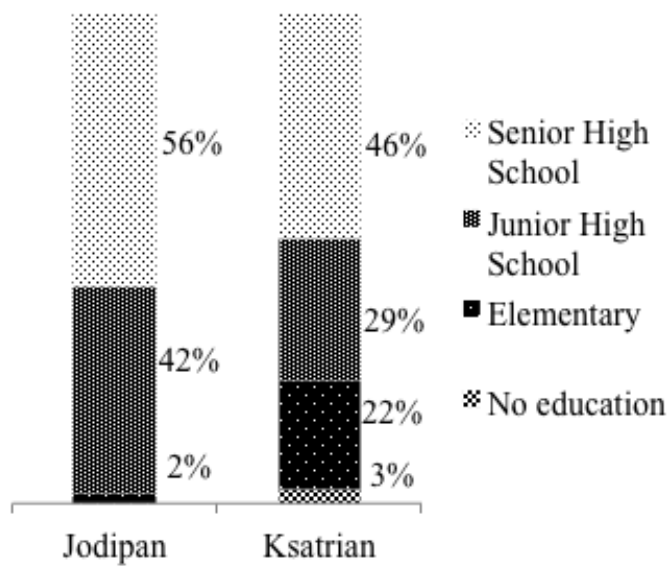

Figure 3 Residents Educational level

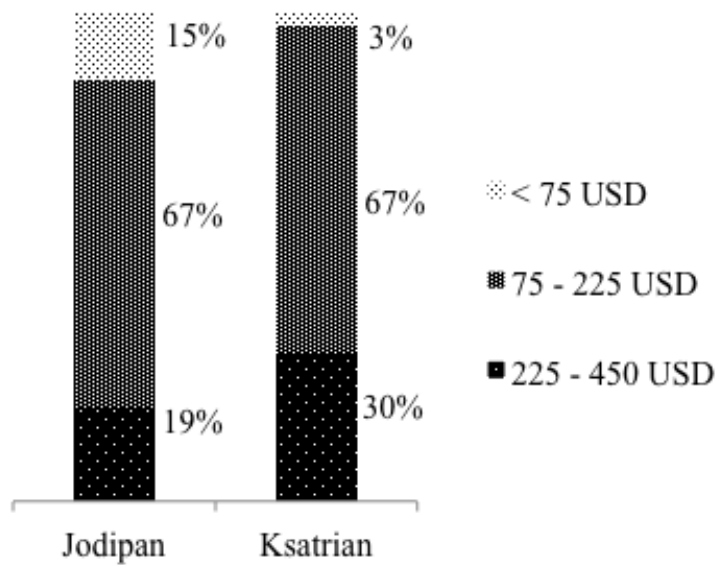

Figure 4 Residents monthly income per household

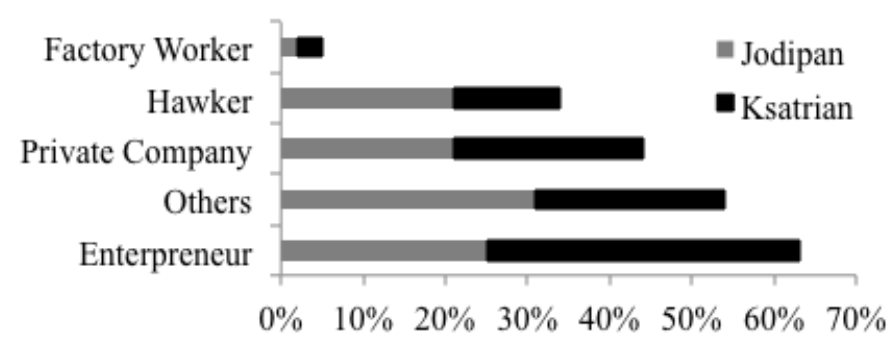

Figure 5 Household head employment sector in Jodipan and Ksatrian

were also called upon to decorate the neighborhood.

Other than the visual changes, in Jodipan Village the project also brought a new municipal solid waste collecting system for the neighborhood, which uses the entrance money of 2,000 IDR paid by tourists to enter the neighborhood. The new system helped change residents behavior that was used to litter directly into the river. In this new system, the community arranges for a garbage collection system from the trash bin in front of their house to the temporary garbage disposal area, and also they can make payment for the collection of their garbage from that temporary garbage disposal area to the landfill. Since the trash bin now is in from of their houses, it became more convenient than throwing the trash directly to the river.

After the project in Jodipan had progressed, there was a request by the local government to extend the project into the neighboring Ksatrian. PT. Indana agreed to be involved in the extension this coloring as well. However in this initiative, the students were not involved, therefore there was little to no briefing about the motivation of the project as a means to change residents' behavior. Also unlike Jodipan, Ksatrian already had a municipal solid waste management system in place, where residents are requested to pay between 0.38 USD -0.75 USD per month.

\section{RESULTS AND DISCUSSION}

In this section the results and discussion of the research is presented. Firstly the area demographics are presented to give context to the results, and then the change of behavior towards municipal solid waste management among residents is investigated through two different perspectives, which is the physical waste reduction and the awareness of residents towards waste management.

\section{A. Area demographics}

Through the questionnaire it is possible to investigate the demographics of the community. Both in Jodipan and Ksatrian the majority of the residents have lived in the area for more than 10 years; with $88 \%$ in Jodipan and $93 \%$ in Ksatrian claiming so. Most of the community also claims to own their property, with $88 \%$ in Jodipan and $100 \%$ in Ksatrian, despite the area legally owned by the state. Through the questionnaire also the residents' livelihood, education level, and average monthly income are investigated. 


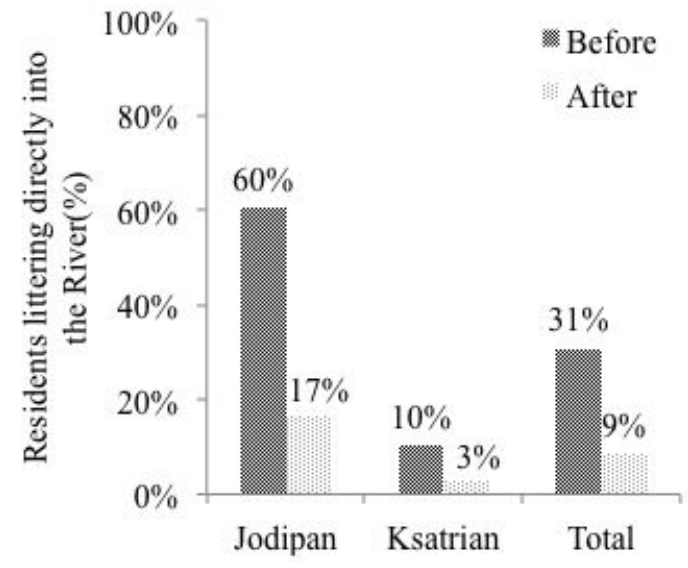

Figure 6 Comparison between the percentage of residents throwing municipal solid waste directly into the river before and after the project

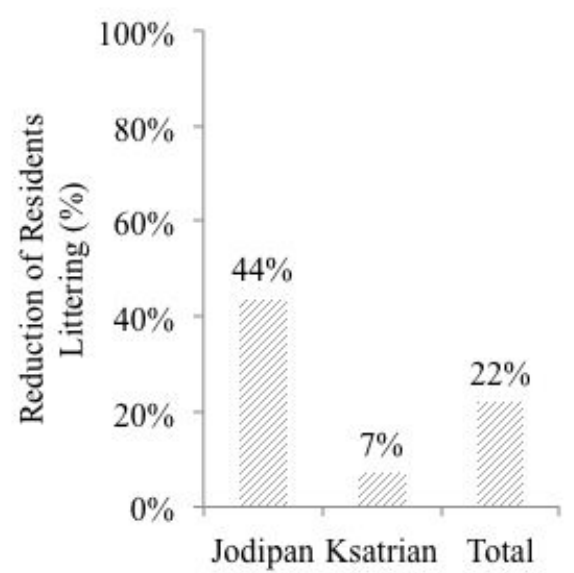

Figure 7 Reduction of residents throwing municipal solid waste directly to the river

(see Figure 7 for clarity). The reduction in Ksatrian is smaller the percentage of residents littering is already smaller initially due to its municipal solid waste management system; while in Jodipan the change of behavior is drastic due to the newly created municipal solid waste management system on top of the visual improvement. This however means that just by the virtue of the visual improvement there is a possible reduction littering into the river up to $7 \%$.

The questionnaire also kept track of the typical volume of trash thrown into the river by each household, so that the volume of the reduction can also be calculated. In Jodipan the reduction of trash is at 1.12 $\mathrm{L} /$ household/day; while in Ksatrian it is at 0.15 L/household/day.

As Guerrero et.al concluded, waste management involves a large number of different stakeholders, with different fields of interest, yet often it is only seen as a responsibility of the local authority. It is best for citizens to be co-responsible with the municipality, so that detailed understanding on who the stakeholders are and the responsibilities they have in the structure can be established in order to achieve an efficient and effective system. It is this communication transfer between the different stakeholders that is at utmost importance in order to get a well functioning waste management system in the cities in developing countries [14].

The case in Jodipan showed that prior to the project there was little understanding in all the steps necessary for all stakeholders, especially from the side of the residents, to get the municipal solid waste from each household to the landfill. The city responsibility only goes from moving the collected municipal solid waste from the temporary waste collection location to the final landfill, but the city does not arrange for household collection of municipal solid waste.

This household collection of municipal solid waste proofs to be useful and appropriate for the need of each household, and also reduces the instances of municipal solid waste thrown into the river. The sustainability of the waste management system is also more secure due to it being funded by the payment received from tourists reduction of both areas is found at $22 \%$, with a bigger reduction Jodipan with $44 \%$ than in Ksatrian with $7 \%$ 
coming inside Jodipan.

\section{Awareness Increase in Municipal Solid Waste Management}

In both areas the residents feel the benefit of the municipal solid waste management system, with $77 \%$ and $73 \%$ of the residents finding it useful for Jodipan and Ksatrian respectively. While the majority of the residents are also willing to be actively involved in the municipal solid waste management system, with $83 \%$ and $98 \%$ agreeing in Jodipan and Ksatrian.

However to see the effect of the project in this increased awareness, a Paired T-Test is performed. The paired t-test showed that there is a significant relationship between the visual improvements of the slum to the awareness of the residents shown in their willingness to throw municipal solid waste into the trash bin, with a p-value of less than 0.05 , which is at 0.045 . The mean increase is at 0.058 with a confidence interval $95 \%$ ranging from 0.001 to 0.115 . The effect size is large with a $\eta^{2}$ of 0.058 ; classification done using the general rules of thumb given by Cohen [15] and Miles\&Shevlin [16].

This means that the visual improvement indeed has a positive relation to the increase in awareness towards municipal waste management system.

\section{CONCLUSION}

Often times not much resources is available for the complete structural change necessary to improve sanitation. In this research the possibility of a simple visual improvement of slums to change the behavior of residents towards municipal solid waste management is investigated in the case of Jodipan and Ksatrian in Malang, East Java, Indonesia. It is found that there is a significant reduction of residents who litter directly into the river after the visual improvement. The total reduction is at $22 \%$, with a reduction of $44 \%$ in Jodipan and $7 \%$ in Ksatrian. The reduction in Jodipan is found much more significant because there was no initial municipal solid waste management system installed before the project, making the possible reduction much larger. However even in the case of Ksatrian that already had a municipal solid waste management in place before, the change in behavior is still significant with a $7 \%$ reduction of littering directly into the river cases. The total volume reduction of municipal solid waste thrown into the river directly is at $1.12 \mathrm{~L} /$ household/day in Jodipan and $0.15 \mathrm{~L} /$ household/day in Ksatrian.

There is also a significant relationship between the visual improvements of the slum to the awareness of the residents shown in their willingness to throw municipal solid waste into the trash bin, with a p-value of less than 0.05 , which is at 0.045 . The effect size is large with a $\eta^{2}$ of 0.058 .

\section{ACKNOWLEDGEMENT}

The Authors would like to extend gratitude towards the Research, Community Development and Study Group Innovation Program 2017 (Program Penelitian, Pengabdian Masyarakat dan Inovasi Kelompol Keahlian - P3MI) of Institute Technology of Bandung (ITB) for funding this research. The study was carried out with the help of the waster and wastewater engineering study group of the Faculty of Civil and Environmental Engineering ITB. The cooperation of Guys Pro, PT Indana and Mr. Jamroji as lecturer from University of Muhammadiyah Malang is also greatly appreciated. Authors are also grateful for the statistical consultancy input of Mr. Dodon Turgana Tarmidi, lecturer at the Urban Planning Department of the University of Winaya Mukti.

\section{REFERENCES}

[1] WHO and UNICEF (Joint Monitoring Program), Progress on Sanitation and Drinking-Water: 2013 Update.: WHO and UNICEF, 2013.

[2] R.W. Mathenge M.A.C. Schouten, "Communal sanitation alternatives for slums: a case study of Kibera, Kenya," Physics and Chemistry of the Earth, vol. 35, pp. 815-822, 2010.

[3] Central Investigation Agency. www.cia.gov. [Online]. www.cia.gov/library/publications/theworld-factbook/

[4] UN-Water Global Analysis and Assesment of Sanitation and Drinking Water, "Progress on Drinking and Sanitation, Country Highlights:Indonesia," WHO, 2015.

[5] Asian Development Bank, "Sector Assesment (Summary):Sanitation, Urban Sanitation and Rural Infrastructure Support to the PNPM Mandiri Project (RRP INO 43255-01)," ADB, 2009.

[6] State Ministry of Environment, "Indonesian Solid Waste Statistic," The Republic of Indonesia, 2008.

[7] Badan Perencanaan Pembangunan Nasional, "Rencana Pembangunan Jangka Menengah Nasional 2015-2019," Presiden Republik Indonesia, 2014.

[8] International Solid Waste Association, "Globalization and Waste Management; Phase 1: Concepts and facts," International Solid Waste Association, 2012.

[9] Sarika Rathi, "Alternative approaches for better municipal solid waste management in Mumbai, India," Waste Management, vol. 26, no. 10, pp. 1192 1200, 2006

[10] Amita Majumder, Subhendu Chakrabarti Snigdha Chakrabarti, "Public-community participation in household waste management in India: An operational approach," Habitat International, vol. 33, no. 1, pp. 125-130, January 2009.

[11] T.B. Prayogo, Y. Dote, T.Yoshitake, I.Bagus T Sekito, "Influence of a community-based waste management system on people's behavior and waste reduction," Resources, Conservation and Recycling, vol. 72, pp. 84-90, march 2013.

[12] Graham A. Moore, Guntur Sitorus Haskarlianus Pasang, "Neighborhood-based waste management: A solution for soid waste problems in jakarta, Indonesia," Waste Management, vol. 27, pp. 19241938, 2007.

[13] Badan Pusat Statistik. www.bps.go.id. [Online]. https://www.bps.go.id/linkTabelStatis/view/id/1525

[14] Ger Maas, William Hogland Lilliana Abarca 
The Third International Conference on Civil Engineering Research (ICCER)

August $1^{\text {st }}-2^{\text {nd }} 2017$, Surabaya - Indonesia

Guerrero, "Solid waste management challenges for cities in developing countries," Waste Management, vol. 33, no. 1, October 2012.

[15] J.Cohen, Statistical power analysis for the behavioural sciences , 2nd ed.: Hillsdale,NJ:Erlbaum, 1988.

[16] M.Shevlin J.Miles, Applying Regression and Correlation: A Guide for Students and Researchers. London: Sage, 2001. 